Kinga Kowalczyk-Purol

\title{
Religia w perspektywie \\ ewolucjonistycznej, \\ ze szczególnym uwzględnieniem jej funkcji socjalizacyjnej
}

Celem niniejszej pracy jest przedstawienie i analiza hipotez formułowanych $\mathrm{w}$ ramach podejścia ewolucjonistycznego, które próbują tłumaczyć powstanie i trwanie religii poprzez jej - domniemywana w tych hipotezach - doniosłą rolę w harmonizowaniu oraz konsolidowaniu społeczeństw. Na samym wstępie należy jednak zaznaczyć, że wyjaśnienie tak skomplikowanego zjawiska, jakim jest ludzka religijność, poprzez sprowadzenie jej do warstwy wspólnotowej jest raczej skazane na niepowodzenie. Religia, jak wiadomo, to nie tylko element kultury. Poza wymiarem społecznym, czy też instytucjonalnym, jest ona również bardzo ważnym czynnikiem kształtującym osobisty światopogląd oraz kluczowe doświadczenia w życiu ludzkim (vide doświadczenia religijne), które można określić jako aspekt emotywny religii. Nadto nieodzownym składnikiem każdej religii jest jej doktryna zawierająca treści dotyczące, z grubsza rzecz ujmując, koncepcji powstania oraz celu świata, a także pewne kodyfikacje norm moralnych. Tak więc geneza oraz funkcja religii, mimo jej niezaprzeczalnie istotnej roli w sferze publicznej, nie może być wyjaśniona za pomoca wiedzy z zakresu wpływu religii na dobrostan i powodzenie grup ludzkich.

Niemniej jednak ze względu na wspomniany doniosły wkład religii w kondycję wspólnot ludzkich oraz pewny zastój w obszarze 
podejścia eksplanacyjnego ${ }^{1} \mathrm{w}$ badaniach nad religia, wydaje się, że analiza nowego ${ }^{2}$ i obiecującego podejścia, czyli właśnie aplikacji narzędzi wyjaśniających oraz terminologii ewolucjonizmu do badań nad zjawiskami niebiologicznymi, jest badawczo wartościowa. Darwinizm kosmiczny ${ }^{3}$, bo taka właśnie nazwa przyjęła się w polskiej literaturze na określenie praktyki badawczej polegajacej na przenoszeniu ram teoretycznych darwinizmu poza oryginalny ( $\mathrm{tj}$. biologiczny) obszar badań, jest wielostronnie i intensywnie rozwijanym, by odwołać się do sformułowania używanego przez Andrzeja Klawitera, mega paradygmatem - czyli teoretyczna matryca służaca powielaniu kolejnych bardziej wyspecjalizowanych paradygmatów ${ }^{4}$.

Takie optymistyczne względem darwinizmu kosmicznego stanowisko jest ufundowane w głównej mierze na powodzeniu włączania

1 Należy odróżnić przedsięwzięcia o charakterze opisowym (deskryptywnym) religii, jak chociażby etnologię i fenomenologię religii, od badań mających na celu jej wyjaśnienie, np. zależności struktury danej religii od warunków ekonomiczno-ustrojowych.

2 Posłużenie się kategorią „nowy” w kontekście ponad stupięćdziesięcioletniej historii darwinizmu wymaga dookreślenia. W historii nauki można wyodrębnić, różne od omawianych w tej pracy, ewolucjonistyczne teorie religii. Powstawały one już na przełomie XIX i XX wieku, a ich główne źródło powstania należy upatrywać w ogólnym entuzjazmie towarzyszacym pierwszej fali propagacji biologicznej teorii ewolucji. Do autorów konstruujących te wcześniejsze ewolucjonistyczne teorie religii należy zaliczyć m.in. Johna Lubbocka, Edwarda Tylora czy Lewisa H. Morgana. Od współczesnych ewolucjonistycznych teorii religii odróżniały się one skupieniem na wyróżnianiu poszczególnych stadiów, tak zwanych wyższych form religii w ich linearnym rozwoju. Natomiast obecne ewolucjonistyczne teorie religii kładą akcent na wdrażanie, czy też zastosowanie kategorii eksplanacyjnych swoistych dla darwinizmu (np. adaptacja, wyścig zbrojeń). Por. M. Nowaczyk, Ewolucjonizm kulturowy a religia, Warszawa 1989, s. 9-30.

3 Niestety wydaje się, że określenie „darwinizm kosmiczny”, które jest tłumaczeniem angielskiego terminu universal Darwinism, w polskim kontekście językowym prowokuje wiele nieporozumień. Tym samym nie można stwierdzić, że jest to precyzyjny (ostry) termin naukowy. Przede wszystkim określenie to budzi skojarzenia z ewolucją kosmosu, a więc prowadzi do zawężenia tego rozległego i ekspansyjnego programu badawczego zaledwie do jednej z wielu dziedzin, do której ma być stosowany. Niemniej, ze względu na fakt użycia tego określenia w polskich tłumaczeniach bardzo ważnych dla tego zagadnienia książek (m.in. Samolubnym genie Richarda Dawkinsa oraz Maszynie memowej Susan Blackmore) w niniejszej pracy termin ten również będzie stosowany.

4 Por. A. Klawiter, Teoria ewolucji a ewolucjonizm: od koncepcji biologicznej do mega paradygmatu myślowego, [w:] Teoria i metoda w biologii ewolucyjnej, red. K. Łastowski, Poznań 2004, s. 238-239. 
ewolucjonizmu do dociekań nad zjawiskami, które wydawały się znajdować poza ramą koncepcyjna tego podejśsia ${ }^{5}$. Najbardziej spektakularnym przykładem jest altruizm, który dotychczas był uważany za zachowanie specyficznie ludzkie, a przez to wymykajace się standardom poznania naukowego. Jednak dokonania badawcze takich naukowców, jak George C. Williams, William D. Hamilton oraz Robert Trivers praktycznie umożliwiły matematyzację altruizmu ${ }^{6}$. Nadto, ze względu na ową wielowymiarowść religii jest ona właściwym obiektem do przetestowania możliwości wyjaśniajacych samej praktyki rozszerzania podejścia ewolucjonistycznego na zjawiska niebiologiczne.

\section{Charakterystyka paradygmatu ewolucjonistycznego}

W ewolucjonistycznych teoriach religii (zwanych również czasami biopsychologicznymi), co oczywiste ze względu na ich przyrodoznawcze korzenie, nie analizuje się logicznych racji niuansów teologicznych. Filozoficzna warstwa twierdzeń religijnych, a więc ich spójność i szeroko rozumiana racjonalność, nie stanowi centrum zainteresowania dla omawianego podejścia. Innymi słowy, sensowność i racjonalne uzasadnienie treści doktryn religii są na gruncie ewolucyjnym traktowane drugorzędnie. Jest tak ponieważ paradygmat darwinowski wpisuje się w konkurencyjny nurt badań nad religia. Obok zasygnalizowanego powyżej, by tak rzec, logicystycznego podejścia, można bowiem wyróżnić także podejście skupiające wysiłki badawcze na genezie i funkcji religii ${ }^{7}$. A tymi właśnie obszarami dociekań są zainteresowani darwiniści ${ }^{8}$.

5 Por. Z. Piątek, Pawi ogon. Czyli o biologicznych uwarunkowaniach kultury, Kraków 2007, s. 56-72.

6 Por. W. J. Ray, Evolutionary Psychology: Neuroscience Perspectives concerning Human Behavior and Experience, London 2013, s. 17-20.

7 Por. S. Sztajer, Naturalne podstawy religii $w$ ujęciu religioznawstwa kognitywnego, „Przegląd Religioznawczy” 2008, z. 2 (228), s. 95-96.

8 Por. S. Atran, A. Norenzayan, Religion's evolutionary landscape: Counterintuition, commitment, compassion, communion, „Behavioral and Brain Sciences” 2004, Vol. 27, Issue 6, s. 728. 
Z kwestia poszukiwania adekwatnego wyjaśnienia genezy oraz funkcji religii ściśle łączy się problematyka konceptualizacji religii w tym programie badawczym. Mianowicie podstawowym metodologicznym założeniem spotykanym w ramach ewolucjonistycznych teorii religii jest zamysł uniwersalizującego ujęcia religii. Innymi słowy, na darwinowskim gruncie dąży się do, przywołując popularne ostatnimi czasy sformułowanie, skonstruowania „wielkiej narracji”, która miałaby koncepcyjnie obejmować wszystkie znane manifestacje religii. Posługując się klasyczną już dystynkcją: nomologiczny/idiograficzny, należy stwierdzić, że ewolucjoniści aspirują do wpisania się w ten pierwszy trend badawczy. Niemniej jednak, mając na uwadze fakt, że sama biologia nie ma charakteru czysto nomologicznego (w jej przypadku należy raczej mówić o pluralizmie wyjaśnień ${ }^{10}$, a więc założeniu, że to cel badawczy decyduje o przyjęciu danej metody), należy stwierdzić, iż postulowana przez adeptów nurtu ewolucjonistycznego nomologiczność jest tylko celem, czy też obrazowo rzecz ujmując, horyzontem poznawczym regulujacym praktykę badawcza, który jednak nigdy nie zostanie osiagnięty.

Co więcej, takie podejście do studiowanego przedmiotu jest rozbieżne z akcentowana przez współczesne kulturoznawstwo swoistością każdej kultury. Innymi słowy, głównym wnioskiem formułowanym przez naukowców, którzy zajmują się badaniem kultur, jest unikatowość każdej z niej. Stąd należałoby dodać, że prezentowane tu stanowisko metodologiczne odznacza się tak zwaną etycznością podejścia, czyli rekonstruowaniem zjawiska religii z zewnattrz, tj. z perspektywy obserwatora, a nie wyznawcy konkretnego obrządku ${ }^{11}$. Jest to biegunowo odmienna perspektywa od metody emicznej, której zwolennicy utrzymuja, że badacz winien

9 Por. A. Szyjewski, Rozbite kubki po dekonstrukcji: wspótczesne antropologiczne teorie religii, „Studia Religiologica” 2007, t. 40, s. 137.

10 Por. I. Brigandt, Explanation in Biology: Reduction, Pluralism, and Explanatory Aims, „Science \& Education” 2013, Vol. 22, s. 87-89.

11 Por. D. Motak, Religia w perspektywie antropologii kognitywnej, [w:] Religioznawstwo polskie w XXI wieku, red. Z. Stachowski, Tyczyn 2005, s. 210-212. 
przyjać postawę empatyczną względem badanego zjawiska kulturowego, a więc - przynajmniej doraźnie - zostać jego uczestnikiem.

Kolejnym wyróżnikiem kierunku ewolucjonistycznego jest pluralizm stanowisk w odniesieniu do takich kwestii, jak hipotetyczna adaptacyjność religii, ale też jej zależność ontyczna od, z grubsza rzecz ujmujac, kultury oraz biosfery. Co istotne z punktu widzenia metodologicznych niuansów całego omawianego tu przedsięwzięcia, odmienność poszczególnych stanowisk w perspektywie ewolucyjnej wobec dostosowawczej roli religii, jak i jej relacji względem porządków biologicznych i kulturowych, często stanowi kryterium podziału ewolucjonistycznych teorii religii na oddzielne (typy) bloki wyjaśnień.

I tak, wyjaśnienia socjobiologiczne ${ }^{12}$ ujmują religię jako fenomen, u podstaw którego stoi jego przystosowawcza wartość dla ludzkiej dzietności oraz przeżywalności ${ }^{13}$. Takie postawienie sprawy jest konsekwencja przypisywania pierwszeństwa imperatywom biologicznej ewolucji (przede wszystkim maksymalizacji liczby potomków), programowo wpisanego w socjobiologiczne rozważania ${ }^{14}$. Warto w tym miejscu przytoczyć słynna - streszczająca istotę socjobiologii - frazę Edwarda O. Wilsona, koryfeusza tej gałęzi nauki, że „geny trzymaja kulturę na smyczy”.

Kolejna propozycją teoretyczna w rodzinie ewolucjonistycznych teorii religii jest memetyka, która, warto to odnotować, wzbudza

12 Należy dopowiedzieć, że socjobiologia to bezpośredni protoplasta psychologii ewolucyjnej, która jest święcącym obecnie duże sukcesy paradygmatem badań nad ewolucyjnym pochodzeniem poszczególnych predyspozycji psychicznych ludzi.

13 Por. S. Blackmore, Maszyna memowa, Poznań 2002, s. 296.

14 Jednak jak trafnie wyłuszcza w swej pracy znawczyni problematyki socjobiologicznej Zdzisława Piątek: „Wbrew oskarżeniom o biologiczny determinizm, Wilson nie uważa, że geny określają bezpośrednio konkretne sposoby realizacji niezbywalnych ludzkich potrzeb, gdyż jest to funkcja kultury. [...] Większość cech organizmu, a zwłaszcza cechy behawioralne, są uwarunkowane przez wiele genów, które współdziałają ze sobą na rozmaite - często niezwykle wyrafinowane - sposoby" (Z. Piątek, Pawi ogon. Czyli o biologicznych uwarunkowaniach kultury, Kraków 2007, s. 48). W świetle tej wypowiedzi należy dookreślić, że twórca socjobiologii odrzucał, sit venia verbo, wulgarny determinizm biologiczny na rzecz umiarkowanej koewolucji geny-kultura. 
jeszcze większe kontrowersje aniżeli wspominana powyżej socjobiologia. Można wręcz zaryzykować wniosek, że owocem tej kontrowersyjności jest marginalizacja memetyki. Zapewne przyczyna ograniczonej afirmacji tego modelu ujmowania kultury i zarazem kondycji człowieka jest, w głównej mierze, depersonalizacja, czy też odpodmiotowienie osoby ludzkiej. W ramach tego paradygmatu utrzymuje się bowiem, że bezprecedensowa złożoność ludzkiego układu nerwowego była niejako ontycznym przyczynkiem do ukonstytuowania się drugich po genach i jakościowo różnych od nich replikatorów - memów. Richard Dawkins, naukowiec, który ukłuł termin „mem” i dał podstawy teoretyczne tej dyscyplinie, w następujący sposób pisze o analogii między genami i memami:

Tak jak geny rozprzestrzeniaja się w puli genowej, przeskakując z ciała do ciala [podkreślenie moje - K. K.-P.] za pośrednictwem plemników lub jaj, tak memy propagują się w puli memów, przeskakując z jednego mózgu do drugiego w procesie szeroko rozumianego naśladownictwa ${ }^{15}$.

Z przytoczonego cytatu wynika, że memy - analogicznie do biologicznych genów - sa samolubnymi, to jest dazżacymi do pozostawienia po sobie jak największej liczby kopii, replikatorami. Ponadto $\mathrm{w}$ zasadzie tylko ludzie ${ }^{16}$ sa $\mathrm{tzw}$. wehikułami przetrwania dla memów (i równocześnie dla genów oczywiście). W memetycznej wizji człowiek jest więc zredukowany do futerału, pokrowca na geny i memy ${ }^{17}$. Łatwo dostrzec, że religia w memetyce jest właśnie definiowana jako mem, a ściślej rzecz ujmując, z uwagi na swą złożoność, mempleks, który jest zharmonizowaną pulą memów czerpiących z tego wspólną korzyść. Dawkins, którego popularność - dzięki jego krańcowo antyreligijnemu usposobieniu - przejawia się nawet w świecie popkultury, bazując na memetycznych ideach stwierdził,

15 R. Dawkins, Samolubny gen, Warszawa 1996, s. 267.

16 Rzecz jasna, z punktu widzenia gradualizmu ewolucji, nie należy wykluczać jakiejś prototypowej, zarodkowej propagacji memów wśród człowiekowatych.

17 Por. S. Wszołek, Wprowadzenie do filozofii religii, Kraków 2004, s. 47. 
że metaforą oddająca istotę religii jest „wirus umysłu”18. Metafora ta bezpośrednio zakłada negatywny wpływ religii na kondycję człowieka. W swym artykule autor słynnej książki Bóg urojony stwierdza wprost:

Jeśli mam rację, religia nie ma żadnej wartości dla przetrwania jednostek ludzkich lub dla korzyści ich genów. Korzyść, jeśli w ogóle jakaś występuje, to dla samej religii ${ }^{19}$.

Zatem Dawkins, będąc sprzymierzeńcem wirusowej interpretacji memetyki, de facto stwierdza kontrpoduktywność religii.

Bardziej umiarkowany - niepasożytniczy - pogląd na potencjał religii prezentuje inny memetyk, Daniel C. Dennett. Ten amerykański filozof nie wyklucza pozytywnego wpływu religii na, by tak rzec, parametry ewolucyjne człowieka. Co prawda, nie rezygnuje z drobnoustrojowego nazewnictwa Dawkinsa, niemniej jednak stwierdza, że:

[...] nie powinniśmy zapominać, że ogromna większość memów, podobnie jak większość zamieszkujących nasze ciała symbiontów bakteryjnych i wirusowych, jest neutralna lub nawet sprzyjająca żywotności swoich nosicieli ${ }^{20}$.

Tak więc, zdaniem Dennetta, ewentualna korzyść płynąca z ortodoksji i ortopraksji, a więc życia światopoglądowo i obyczajowo zgodnego z doktrynami religijnymi, dla ludzi jest przypadkowa. Po prostu incydentalnie interes ludzi i samolubnych replikatorów może być zbieżny. Co istotne dla podjętych tu rozważań, przykładem, jakim posługuje się Dennett, by zobrazować dodatnią właściwość religii, jest wzmacnianie przez nią solidarności grupowej. Koopera-

18 Por. R. Dawkins, Viruses of the Mind, [w:] Dennett and His Critics: Demystifying Mind, ed. B. Dahlbom, Cambridge 1993, s. 6-13.

19 Tenże, What Use is Religion?, 10.11.2012, <http://www.secularhumanism. org/library/fi/dawkins_24_5.htm>, tłum. własne (10.11.2012).

20 D. Dennett, Odczarowanie. Religia jako zjawisko naturalne, Warszawa 2008, s. 224 . 
cja grupowa, szczególnie w przypadku agresywnie nastawionych ościennych społeczności, ma z oczywistych względów dla człowieka wartość adaptacyjna, ale równocześnie jest korzystna dla religijnego mempleksu. Mempleks bowiem poprzez zapewnienie triumfu swoim nosicielom staje się atrakcyjny dla innych grup i jednostek.

Trzecia grupa propozycji w obrębie ewolucjonistycznych teorii religii, które stanowią główny przedmiot analizy niniejszej pracy, są hipotezy kognitywistyczne. Cechą wyróżniającą tego ujęcia jest wyjaśnianie genezy religii poprzez odwoływanie się do fundamentalnych poznawczych mechanizmów mózgowych, których ludzka predyspozycja do religijności miałaby być produktem ubocznym (z ang. byproduct $)^{21}$. Tak więc koncepcyjnym fundamentem teorii kognitywistycznych jest postulowanie przez zwolenników tego podejścia wyspecjalizowanych, aczkolwiek powiązanych funkcjonalnie, algorytmów poznawczych, których naczelne zadanie to - w ogólności - przetwarzanie informacji. Algorytmów tych nie należy rozumieć anatomicznie, tj. jako wydzielonej struktury mózgowej22. Warto dodać, że taki stan rzeczy, w kontekście dotychczasowych badań nad mózgowymi korelatami szeroko rozumianych przeżyć religijnych, można poczytywać jako zaletę paradygmatu kognitywistycznego. Jest tak, ponieważ wskazuje on na odrzucenie prostych mózgowych (anatomicznych) wyjaśnień monokauzalnych, które są charakterystyczne dla robiącej swego czasu furorę w mediach neuroteologii. Pomimo tego, że jest to uproszczony obraz tej dyscypliny, powszechnym skojarzeniem, jakie budzi neuroteologia, jest poszukiwanie tak zwanego modułu Boga (z ang. God spot), czyli specjalnego miejsca w mózgu odpowiedzialnego za generowa-

21 Por. J. Anderson-Thomson, C. Aukofer, Why We Believe in god(s). A Concise Guide to the Science of Faith, Charlottesville 2011, s. 38-41. Humorystycznym zobrazowaniem rozumienia religii jako produktu ubocznego jest tak zwana hipoteza fast foodu, według której religia stała się, podobnie jak silne łaknienie wysokotłuszczowego i bogatego w cukry jedzenia w bogatych społeczeństwach Zachodu, właściwością maladaptywną (niesprzyjającą dostosowaniu), pomimo iż pierwotnie - tj. w innych warunkach środowiskowych - przyczyniała się do wyższej przeżywalności.

${ }_{22}$ Por. M. Miłkowski, R. Poczobut, Czym jest i jak istnieje umyst?, „Diametros” 2005, nr 3, s. 40-44. 
nie wiary religijnej ${ }^{23}$. Co oczywiste, w przypadku wieloaspektowości religii, takie podejście jest po prostu chybione. Kognitywiści poprzez odwoływanie się do wielu, anatomicznie trudnych do zlokalizowania algorytmów poznawczych unikają tego błędu. Niemniej jednak samemu ujęciu kognitywnemu zarzuca się inny typ redukcjonizmu. A mianowicie: zaniedbywanie w swych analizach społecznych i kulturowych czynników kształtujących religię ${ }^{24}$.

W tym miejscu rozważań, w celu przybliżenia głównych założeń leżących u podłoża propozycji kognitywistycznych warto, choćby z grubsza, scharakteryzować kilka wspomnianych powyżej bazowych mechanizmów kognitywnych stanowiących przyczynek do uformowania się religii.

Jednym $\mathrm{z}$ tych mechanizmów jest hiperaktywna detekcja podmiotów intencjonalnych ( $\mathrm{z}$ ang. hyperactive agency detection), której wartość przystosowawcza jest ufundowana na niejako prewencyjnym przypisywaniu intencjonalności przedmiotom i zjawiskom naturalnym (np. uznanie szumu liści za potencjalnego napastnika). Mniej kosztowna jest bowiem omyłkowa ucieczka przed wyimaginowanym drapieżca, niż zignorowanie, czy też niespostrzeżenie go. Kognitywiści twierdza, że religia powstała, między innymi, wskutek wzmocnienia i rozszerzenia tego mechanizmu np. na przedmioty nieożywione i zjawiska atmosferyczne - czego przejawem był animizm - lub też na zmarłych przodków (manizm) ${ }^{25}$.

Innym przykładem mechanizmu poznawczego wskazywanego przez kognitywistów jako rozsadnik religii jest promiskuityzm teleologiczny (z ang. promiscuous teleology). Ten mechanizm kognitywny przyczynia się do powszechnego wśród ludzi finalistycznego interpre-

23 Por. M. Blume, God in the Brain How much can „Neurotheology” explain?, [w:] Zukunftsperspektiven im theologisch-naturwissenschaftlichen Dialog, $\mathrm{Hg}$. P. Becker, U. Diewald, Getynga 2011, s. 306-314.

24 Por. Z. Smith, H. Arrow, Evolutionary Perspectives on Religion: An Overview and Synthesis, „The Journal of the Evolutionary Studies Consortium” 2010, Vol. 2, Issue 2, s. 53.

25 Por. S. Atran, J. Henrich, The Evolution of Religion: How Cognitive By-Products, Adaptive Learning Heuristics, Ritual Displays, and Group Competition Generate Deep Commitments to Prosocial Religions, „Biological Theory” 2010, Vol. 5, Issue 1. s. 20. 
towania losowych zdarzeń. Celowościowy schemat poznawczy promiskuityzmu teleologicznego jest więc ściśle związany z „panintencjonalnościa” hiperaktywnej detekcji. Jak wskazują badania, myślenie teleologiczne ma po prostu wartość komfortująca, by nie powiedzieć terapeutyczna, dla ludzi żyjących w niestabilnych warunkach żywnościowych, bytowych czy społecznych. Twierdzi się, że rzutowanie celowościowego sposobu myślenia na całość życia jednostki może prowadzić do stwierdzenia mówiącego o teleologicznej strukturze całej otaczającej rzeczywistości. A to stwierdzenie jest już solidną przesłanką dla uznania istnienia wyższych, nadnaturalnych bytów, które miałyby kierować otaczajacym światem. W opinii kognitywistów mechanizm ten przejawia się w najbardziej jaskrawy sposób wśród dzieci:

Jeżeli zapytasz się dziecka, czemu służą jeziora, może ono odpowiedzieć, że dla ryb, by mogły w nich pływać. Po co sa ptaki? Dla śpiewu. Po co są kamienie? Po to, by zwierzęta mogły się nimi drapać. [...] Dzieci spontanicznie będą adoptować koncepcję Boga i zaprojektowanego świata, bez interwencji dorosłych ${ }^{26}$.

Trzecim, przykładowym, układem kognitywnym jest łatwowierność dziecięca (z ang. childhood credulity). Z ewolucyjnego punktu widzenia posłuszeństwo dzieci względem rodziców (w szczególności) oraz innych dorosłych jest przystosowawcze. Każda osoba jest w stanie wyobrazić sobie, jak niebezpieczny byłby nonkonformizm dziecięcy. Tradycyjnie przywoływanym przykładem jest wytłumaczenie dziecku, czym grozi dotykanie goracego żelazka. Swojego rodzaju przedłużeniem tego układu jest religijność filiacyjna, czyli powszechność dziedziczenia systemu wierzeń rodziców przez ich dzieci. Stąd innowierstwo jest postawą wyjątkowo rzadka, zwłaszcza w społeczeństwach tradycyjnych ${ }^{27}$.

26 J. Anderson-Thomson, C. Aukofer, Why We Believe in $\operatorname{god}(s)$..., dz. cyt., s. 71 (tłum. własne).

27 Gwoli uzupełnia rozważań należy wspomnieć o przysojeniu pomysłów wielkiego amerykańskiego językoznawcy Noama Chomskyego przez badaczy zajmujących się naturalistycznymi wyjaśnieniami religii. Same zdolności językowe ludzi, zdaniem Chomskyego, sa zdeterminowane przez biologiczne struktury, natomiast 


\section{Trudności metodologiczno-koncepcyjne przedsięwzięcia}

Przed przejściem do zagadnień bezpośrednio związanych z socjalizujacymi mechanizmami religii warto - choćby w zarysie - przedstawić zarzuty, jakie stawia się założeniom koncepcyjno-metodologicznym ewolucjonistycznych teorii religii. Zabieg ten pomoże lepiej zorientować się w obecnej kondycji tej perspektywy badawczej, tj. w jej ograniczeniach oraz możliwościach.

Po pierwsze, kwestią sporną jest, czy zastosowanie instrumentarium oraz terminologii ewolucjonistycznej w sferze zagadnień kulturowych, w tym religii, ma charakter izomorficzny, czy też analogiczny. Izomorficzność wdrażania darwinizmu prowokuje pytanie dotyczące zasadności przenoszenia teorii, która jest wydajna eksplanacyjnie na danym obszarze (albo wręcz poziomie) zagadnień na zupełnie inny obszar badań. Natomiast analogiczność wiąże się z niebezpieczeństwem „metaforyzacji nauki”, czyli osłabianiem znaczenia - bardzo ważnej dla nauki - praktyki operowania możliwie najbardziej precyzyjnymi terminami, która jest niejako ideą regulatywną nauki ${ }^{28}$. Niemniej należy jednak nadmienić, że trzecia, po izomorfii oraz analogii, możliwą konceptualizacja darwinizmu kosmicznego jest generalizacja. Zwięźle rzecz ujmując, generalizacja oznacza w tym kontekście wyodrębnienie wspólnego oraz wysoce abstrakcyjnego rdzenia teoretycznego procesów przebiegających w jakościowo różnych strukturach ${ }^{29}$.

nauka danego języka jest zależna od środowiska kulturowego, w którym funkcjonuje dziecko. Analogicznie zdolność do religijności miałaby być uwarunkowana genetycznie, a przysposobienie konkretnej wiary zależne od kontekstu kulturowego. Por. B. G. Purzycki, R. Sosis, The Religious System as Adaptive: Cognitive Flexibility, Public Displays, and Acceptance, [w:] The Biological Evolution of Religious Mind and Behavior, eds. E. Voland, W. Schiefenhövel, Berlin 2009, s. 244 n.

28 Por. L. H. Martin, Can Religion Really Evolve? (And what it is anyway?), [w:] The Evolution of Religion. Studies, Theories \& Critiques, eds. J. Bulbulia, R. Sosis, E. Harris i in., Santa Margarita 2008, s. 349.

29 Por. H. E. Aldrich i in., In Defence of Generalized Darwinism, „Journal of Evolutionary Economics" 2008, Vol. 18, Issue 5, s. 579. 
Drugim punktem, wokół którego toczą się ostre polemiki naukowców zajmujących się ewolucjonistycznymi teoriami religii, jest poziom analizy. Chodzi o to, czy powinno się analizować działanie procesów ewolucyjnych z perspektywy interesów genów, memów, bądź też populacji ludzkiej ${ }^{30}$.

Problem odpowiedniego doboru poziomu analizy jest sprzężony z inną trudnościa, na którą natrafiaja adepci darwinizmu kosmicznego. Mianowicie jest to brak dominujaceej perspektywy, której funkcją byłoby ogniskowanie wokół siebie nowej koncepcji ${ }^{31}$.

Ostatnią zasygnalizowana tu komplikacją jest, wcześniej już wspomniany, problem definicji religii. Religię na gruncie darwinizmu kosmicznego pojmuje się uniwersalistycznie, pomimo niezwykle zróżnicowanych manifestacji religii. Wydaje się, że esencjalizowanie, czyli stwierdzanie istnienia jakiejś niezmiennej oraz wiecznej natury, tak nieostrego i płynnego fenomenu, jakim jest religia poprzez wydzielenie jakiegoś jej przejawu jest sprzeczne z samą logika metodologii ewolucjonistycznej, która akcentuje płynność i dynamiczność otaczającej rzeczywistości.

\section{Socjalizujące mechanizmy religii}

Zgodnie z tym, co zostało wspomniane powyżej, ze względu na brak miejsca na szerszą charakterystykę stanowisk wszystkich głównych ewolucjonistycznych wyjaśnień religii dotyczacych jej integracyjnej funkcji, przedmiotem bardziej pogłębionej analizy będą wypowiedzi badaczy perspektywy kognitywistycznej. Niemniej jednak warto zauważyć, że to kognitywistyczne wyjaśnienia są obecnie najintensywniej rozwijane oraz że często odwołują się one do argumentu wzajemnego wpływu religii i ludzkich zbiorowości.

30 Por. D. Fetchenhauer, Evolutionary Perspectives on Religion - What They Can and What They Cannot Explain (Yet), [w:] The Biological Evolution..., dz. cyt., s. $281 \mathrm{n}$.

31 Por. tamże, s. 282. 
Wśród „społecznych” mechanizmów poznawczych szczególna rola przypada altruizmowi krewniaczemu oraz odwzajemnionemu. Altruizm krewniaczy jest przyczyną ukształtowania się wśród zwierząt zdolności do poświęcania się dla spokrewnionych organizmów, z którymi altruista dzieli wspólne geny ${ }^{32}$ : „[...] polega to na wpojeniu łagodnego i uogólnionego altruizmu, którego nasilenie zależy od przeciętnego stopnia pokrewieństwa $[. . .]^{\prime 33}$. Tak więc heroizm i ofiarność - zgodnie z ekonomia altruizmu krewniaczego - będą silniejsze w stosunku do matki, z którą altruista dzieli 50 procent genów, niż względem babki, z którą wspólnota genów wynosi już tylko 25 procent. Religia w tym ujęciu wzbudza empatię do współwyznawców poprzez wdrożenie i rozpowszechnianie takich określeń, jak: Bóg Ojciec, Matka Boża, współbracia, współsiostry itp. Słowem, grupy religijne markują więzi rodzinne poprzez mechanizm altruizmu krewniaczego, aby wykorzystać jego solidaryzujący potencjał. Jeszcze inaczej rzecz ujmując, religia po prostu eksploatuje obfite ludzkie pokłady nepotyzmu ${ }^{34}$.

Spekuluje się, że drugi z altruizmów, odwzajemniony, który w przybliżeniu polega na obopólnej wymianie przysług i dóbr, mógł być zalążkiem afirmacji działania, u którego podstaw leży odroczona wypłata ${ }^{35}$. Ten rodzaj altruizmu jest właściwie rozszerzeniem działania altruizmu krewniaczego na osobniki niepowiązane wspólnym dziedzictwem genetycznym, co przyczynia się do złagodzenia agresji wewnątrzgrupowej. Warto podkreślić, że nawet u podłoża sprawnej relacji między bliskimi krewnymi znajduje się współpraca, której fundamentem jest wzajemnośćc ${ }^{36}$. Powszechnie wiadome jest, że religie mocno promują wielkoduszność, miłosier-

32 Altruizm krewniaczy jest najlepiej zharmonizowany z genocentryczną koncepcją ewolucji, w której twierdzi się, że to geny podlegają doborowi naturalnemu, a nie np. indywidualny osobnik bądź populacja.

33 R. Wright, Moralne zwierzę. Dlaczego jesteśmy tacy, a nie inni: psychologia ewolucyjna a życie codzienne, Warszawa 2004, s. 149.

${ }_{34}$ Por. D. C. Lahti, The Correlated History of Social Organization, Morality, and Religion, [w:] The Biological Evolution..., dz. cyt., s. 73.

35 Wchodząc na jeszcze wyższy poziom spekulacji, można powiedzieć, że owa rudymentarna forma odroczonych korzyści mogła być źródłem religijnej soteriologii.

36 Por. D. C. Lahti, The Correlated History..., dz. cyt., s. 74-76. 
dzie oraz współczucie wobec współwyznawców. Z perspektywy ewolucjonistycznej jest to przejaw działania altruizmu wzajemnego.

Plaga każdego, nawet najbardziej monolitycznego, społeczeństwa jest problem tzw. jazdy na gapę (z ang. free-rider problem). Pomimo ogólnej korzyści, jaką osobniki czerpia z powszechności altruizmu jako grupa oraz jako indywidua, pasożytnictwo na altruistach jest jeszcze bardziej opłacalne, przynajmniej dla części jednostek w skali społeczeństwa. Te pasożytnicze jednostki, nie dokonując żadnej inwestycji ze swojej strony, korzystaja z dobrodziejstw społeczeństwa altruistycznego. Flagowym przykładem dla tego zjawiska jest właśnie jazda na gapę np. środkami komunikacji miejskiej. W sukurs utrzymania spójności społeczeństwa przychodzi religia. Antropolog ewolucyjny Richard Sosis zaproponował hipotezę religii jako kosztownego sygnalizowania, która ma wyjaśniać problematyczna dla teorii ewolucji, bezprecedensowa, czy wręcz ekscentryczną ofiarność ludzi religijnych. Sosis podaje następujące przykłady:

Australijscy aborygeni przeprowadzają rytualną operację na nastoletnich chłopcach, podczas której kość lub kamień jest wkładany do penisa przez cewkę moczową. Żydzi oraz muzułmanie poddają swoich synów obrzezaniu, a w niektórych społecznościach muzułmańskich również córki są podmiotem obrzezania lub innej formy okaleczania genitaliów. [...] Ceremonie inicjacyjne, znane również jako obrzędy przejścia, sa często brutalne. Pośród rdzennych Amerykanów, chłopcy z plemienia Apaczów są zmuszani do kapieli w lodowatej wodzie ${ }^{37}$.

Zdaniem tego badacza przytoczone powyżej zachowania sa formą kosztownego sygnalizowania, które należy rozumieć jako wiarygodne komunikowanie przywiązania do konkretnej grupy religijnej. Wiarygodność komunikatów jest oparta na znacznej inwestycji czasowej, energetycznej oraz finansowej sygnalizujacego. (Dewo-

${ }^{37}$ R. Sosis, The Adaptive Value of Religious Ritual. Rituals Promote Group Cohesion by Requiring Members to Engage in Behavior that is too Costly to Fake, „American Scientist” 2004, Vol. 92, No. 2, , s. 167 (tłum. własne). 
cyjna manifestacja lojalności byłaby po prostu zbyt kosztowna, gdyby okazała się oszustwem.) Zaufanie między współwyznawcami ma wówczas solidną bazę empiryczną i jest dobrą podstawą do budowania efektywnej kooperacji ${ }^{38}$. W ten sposób ze społeczeństwa eliminuje się pasożytniczych gapowiczów.

Sosis wskazuje na dwa przykłady, które zwiększają konfirmację tej hipotezy. Pierwszy odnosi się do założenia przez nia powstania następującej zależności: im większy koszt komunikatu, tym bardziej gorliwa dewocja sygnalizującego. Jest to swoisty paradoks religii. Grupy wyznaniowe, które oczekują od wyznawców większego poświęcenia (np. odróżniającego od reszty społeczeństwa ubioru, który nierzadko jest czynnikiem stygmatyzującym), notują większe sukcesy rekrutacyjne. Ilustracją tego zjawiska są współczesne grupy wyznaniowe, takie jak Świadkowie Jehowy, mormoni, Kościół Adwentystów Dnia Siódmego, które odznaczając się ciężkimi wymogami, zarazem cieszą się wysokimi wskaźnikami wzrostu liczby wiernych. Natomiast bardziej liberalne Kościoły rejestruja spadek liczby wyznawców ${ }^{39}$.

Druga prognozą wynikająca z hipotezy kosztownego sygnalizowania, nazywanej także hipotezą markerów religijnych, jest zwiększenie kooperacji wewnątrzgrupowej poprzez zachowania wymagające dużego poświęcenia. Sosis testował tę zależność poprzez analizę dziewiętnastowiecznych sekt. Jego badania wykazały, że bardziej integrystyczne odłamy, wymagające - chociażby - celibatu oraz wegetarianizmu, istniały dłużej niż te mniej restrykcyjne ${ }^{40}$.

Mimo empirycznej podstawy hipoteza kosztownego sygnalizowania spotkała się z krytyką. Podano w wątpliwość przede wszystkim samą kosztowość. Wydaje się, że w tradycjonalistycznych społeczeństwach bardziej kosztowne jest nieprzystapienie do dominujaccego Kościoła. To nonkonformizm jest postawa, która niesie ze sobą ogromne ryzyko potępienia społecznego, z kolei oportunizm jest zachowaniem mniej kosztownym. W takim ujęciu nie może budzić zdziwienia brak

38 Por. tamże, s. 168-170.

39 Por. tamże, s. 169n.

40 Por. tamże, s. 170. 
doniesień antropologów o odmawianiu przez młodych mężczyzn uczestnictwa $\mathrm{w}$ obrzędach przejścia (rites de passage) ${ }^{41}$. Inny zarzut wobec propozycji Sosisa dotyczy podważenia koncepcji religii jako markera grupowego. Wiele prac antropologów dokumentuje walki między plemionami wyznającymi tę samą religię. Oprócz dokumentacji antropologów istnieją także prace historyków, które wspominaja, chociażby, o średniowiecznych wojnach w chrześcijańskiej Europie. Dlatego też należy wnioskować, że religia jest tylko jednym z wielu czynników określajaccych przynależność do danej grupy ${ }^{42}$.

Ważne miejsce w wyjaśnieniach kognitywistów zajmuje również mechanizm posłuszeństwa wobec autorytetów. Mechanizm ten jest dobrze udokumentowany w literaturze przedmiotu. Warto wspomnieć tu choćby słynny eksperyment Stanleya Milgrama, w którym istotna rolę odegrała charyzma ${ }^{43}$. Także w grupach religijnych ważną kategoria, przede wszystkim decydującą o miejscu w jej hierarchii, jest charyzma. To charyzmatyczne jednostki w dużej mierze decyduja o losach grup religijnych, o zachowaniu czystości rytuałów oraz ortodoksji. Mechanizm posłuszeństwa wobec autorytetów niesie ze sobą wielkie niebezpieczeństwo wykorzystywania całych grup przez autorytety religijne, które moga kierować się egoistycznymi pobudkami. Przykłady tego typu zachowania osłabiają teze o adaptacyjnej wartości religii dla całych grup ludzkich oraz wartość poznawczą analizy religii z poziomu doboru grupowego ${ }^{44}$.

${ }_{41}$ Por. D. Fetchenhauer, Evolutionary Perspectives on Religion..., dz. cyt., s. 288n. Warto również odnotować, że w ramach hipotezy kosztownego sygnalizowania nie jest istotna autentyczna, pobożna wiara wyznawców w dogmaty religijne zawarte w doktrynach denominacji. Na bazie tej hipotezy wystarczająca jest jedynie tzw. poprawność teologiczna, która odnosi się do zewnętrznego manifestowania przywiązania do prawd wiary, przy równoczesnej wewnętrznej ignorancji bądź nawet negacji ich zgodności z rzeczywistościa. Por. S. Sztajer, Religia w świetle nauk kognitywnych, „Przegląd Religioznawczy”2007, nr 223 (1), s. 30n.

42 Por. D. Fetchenhauer, Evolutionary Perspectives on Religion..., dz. cyt., s. 284.

${ }^{43}$ Por. P. Zimbardo, Efekt Lucyfera. Dlaczego dobrzy ludzie czynia zło?, Warszawa 2008, s. 281-288.

${ }_{4}$ Por. D. Fetchenhauer, Evolutionary Perspectives on Religion..., dz. cyt., s. $382-384$. 
Bardzo ważny dla prowadzonych rozważań jest również kognitywny moduł tendencji do myślenia esencjalistycznego, które, w zarysie, sprowadza się do przypisywania rzeczom oraz zjawiskom stałych cech, czyli - w końcowym rezultacie - przypisywania im niezmiennej istoty. Badania wskazuja, że jest to wrodzony sposób myślenia. Rolą tego mechanizmu jest, przede wszystkim, pomoc jednostkom w usystematyzowaniu wiedzy. Esencjalizm usprawnia bowiem identyfikację oraz rozróżnianie rozmaitych obiektów, przyczynia się również do szybszego wyciagania wniosków ${ }^{45}$. Nadto logika esencjalistyczna, silnie powiązana z tworzeniem stereotypów, jest odpowiedzialna za ukonstytuowanie się podziału MY - ONI. Dychotomia ta wywołuje silny ładunek emocjonalny odpowiedzialny za mobilizowanie jednostek do poświęcania się dla własnej grupy w okolicznościach rywalizacji z innymi grupami. Systemy religijne akomodowały elementy myślenia esencjalistycznego, czego świadectwem jest - nierzadko spotykane - przeciwstawianie przez doktryny religijne prawowiernej społeczności sekciarskiej wierze konkurencyjnej grupy religijnej.

\section{Zakończenie}

Kończąc, przede wszystkim należy stwierdzić niejednorodność całego przedsięwzięcia ewolucjonistycznych teorii religii. Na obecnym etapie rozwoju tego paradygmatu badania religii trudno orzec, czy taki stan rzeczy jest nieusuwalny (tzn. tkwi, by tak rzec, w jego istocie), czy też jest właśnie tylko swoisty dla jego wczesnej fazy. Wspomniana niejednorodność odnosi się do kilku ważnych aspektów ewolucyjnego analizowania religii. Chodzi tu w głównej mierze o takie zagadnienia jak adaptacyjność religii, ale także wskazanie poziomu, na którym dobór naturalny ma faworyzować religijność (poziom genów [resp. memów], poziom indywidualny, poziom grupowy). Istotny jest również stosunek poszczególnych teorii do czyn-

45 Por. B. Saler, Essentialism and Evolution, [w:] The Evolution of Religion..., dz. cyt., s. 379-385. 
ników kulturowych. Poza memetyka, pozostałe dwa stanowiska zdają się bagatelizować wpływ kultury na kształtowanie religii. Warto jeszcze wspomnieć, że całe omawiane w tej pracy przedsięwzięcie wymaga, przede wszystkim, wdrożenia szerszych badań empirycznych, które zweryfikowałyby konkluzywność formułowanych hipotez. Bez tego kroku hipotezy te w dalszym ciagu będa miały status spekulacyjnego dumania nad pochodzeniem i rola religii. Nadto badania empiryczne z pewnością przyczyniłyby się również do większej systematyzacji tego podejścia. Nie można jednak zapominać, że sformułowane hipotezy były już bodźcem i inspiracją do przeprowadzenia eksperymentów nad ewolucjonistyczną genealogia religii ${ }^{46}$. Innym koniecznym krokiem dla rozwoju tego programu badawczego jest nawiązanie ściślejszej współpracy pomiędzy ewolucjonistami, antropologami, socjologami, historykami oraz religioznawcami. Faktyczna, a nie tylko postulowana, interdyscyplinarność zwiększy prawdopodobieństwo uniknięcia spłycających ujęć religii.

\section{Summary}

\section{Religion in Evolutionary Perspective with Particular Reference to Its Socialization Function}

This paper gives an overview of the potential integrative function of religion from the evolutionary standpoint. In order to fulfill those aims, the work first addresses the characterization of the use of an evolutionary paradigm for the study of religion. In this section, the most prominent evolutionary hypotheses of religion are discussed: the sociobiological view, memetic approach and cognitive perspective. Subsequently, the article also introduces several conceptual difficulties of the whole program of Darwinian religious study. In the final part of the paper, a couple of the most important religious mechanisms of social integration are shown.

Keywords: religion, evolution, sociobiology, memetics, cognitive sciences

${ }^{46}$ Por. D. Fetchenhauer, Evolutionary Perspectives on Religion..., dz. cyt., s. 280. 


\section{Bibliografia}

Adlrich H. E. i in., In Defence of Generalized Darwinism, „Journal of Evolutionary Economics” 2008, Vol. 18, Issue 5, s. 577-596.

Anderson Thomson J., Aukofer C., Why We Believe in god(s). A Concise Guide to the Science of Faith, Charlottesville 2011.

Atran S., Norenzayan A., Religion's evolutionary landscape: Counterintuition, commitment, compassion, communion, „Behavioral and Brain Sciences” 2004, Vol. 27, Issue 6, s. 713-770.

Atran S., Henrich J., The Evolution of Religion: How Cognitive By-Products, Adaptive Learning Heuristics, Ritual Displays, and Group Competition Generate Deep Commitments to Prosocial Religions, „Biological Theory” 2010, Vol. 5, Issue 1, s. 18-30.

Blackmore S., Maszyna memowa, Poznań 2002.

Blume M., God in the Brain How much can „Neurotheology” explain?, [w:] Zukunftsperspektiven im theologisch-naturwissenschaftlichen Dialog, $\mathrm{Hg}$. P. Becker, U. Diewald, Getynga 2011, s. 306-314.

Brigandt I., Explanation in Biology: Reduction, Pluralism, and Explanatory Aims, „Science \& Education” 2013, Vol. 22, s. 69-91.

Dawkins R., Viruses of the Mind, [w:] Dennett and His Critics: Demystifying Mind, ed. B. Dahlbom, Cambridge 1993, s. 13-27.

Dawkins R., Samolubny gen, Warszawa 1996.

Dawkins R., What Use is Religion, www.secularhumanism.org/library/fi/dawkins_24_5.htm (10.11.2012).

Dennett D., Odczarowanie. Religia jako zjawisko naturalne, Warszawa 2008.

Fetchenhauer D., Evolutionary Perspectives on Religion - What They Can and What They Cannot Explain (Yet), [w:] The Biological Evolution of Religious Mind and Behavior, eds. E. Voland, W. Schiefenhövel, Berlin 2009, s. 275-291.

Klawiter A., Teoria ewolucji a ewolucjonizm: od koncepcji biologicznej do mega paradygmatu myślowego, [w:] Teoria i metoda $w$ biologii ewolucyjnej, red. K. Łastowski, Poznań 2004, s. 233-242.

Lahti D. C., The Correlated History of Social Organization, Morality, and Religion, [w:] The Biological Evolution of Religious Mind and Behavior, eds. E. Voland, W. Schiefenhövel, Berlin 2009, s. 67-88. 
Martin L. H., Can Religion Really Evolve? (And what it is anyway?), [w:] The Evolution of Religion. Studies, Theories \& Critiques, eds. J. Bulbulia, R. Sosis, E. Harris i in., Santa Margarita 2008, s. 349-355.

Miłkowski M., Poczobut R., Czym jest i jak istnieje umyst?, „Diametros” 2005, nr 3, s. $27-55$.

Motak D., Religia w perspektywie antropologii kognitywnej, [w:] Religioznawstwo polskie w XXI wieku, red. Z. Stachowski, Tyczyn 2005, s. 839-845.

Nowaczyk M., Ewolucjonizm kulturowy a religia, Warszawa 1989.

Piątek Z., Pawi ogon. Czyli o biologicznych uwarunkowaniach kultury, Kraków 2007.

Purzycki B. G., Sosis R., The Religious System as Adaptive: Cognitive Flexibility, Public Displays, and Acceptance, [w:] The Biological Evolution of Religious Mind and Behavior, eds. E. Voland, W. Schiefenhövel, Berlin 2009, s. 243-256.

Ray W. J., Evolutionary Psychology: Neuroscience Perspectives concerning Human Behavior and Experience, London 2013.

Saler B., Essentialism and Evolution, [w:] The Evolution of Religion. Studies, Theories \& Critiques, eds. J. Bulbulia, R. Sosis, E. Harris i in., Santa Margarita 2008, s. 379-386.

Sosis R., The Adaptive Value of Religious Ritual. Rituals Promote Group Cohesion by Requiring Members to Engage in Behavior that is too Costly to Fake, „American Scientist” 2004, Vol. 92, No. 2, s. 166-172.

Sztajer S., Religia w świetle nauk kognitywnych, „Przegląd Religioznawczy” 2007, nr 223 (1), s. 25-38.

Sztajer S., Naturalne podstawy religii w ujęciu religioznawstwa kognitywnego, „Przegląd Religioznawczy” 2008, nr 2 (228), s. 95-106.

Szyjewski A., Rozbite kubki po dekonstrukcji: wspótczesne antropologiczne teorie religii, „Studia Religiologica” 2007, t. 40, s. 135-169.

Wright R., Moralne zwierzę. Dlaczego jesteśmy tacy, a nie inni: psychologia ewolucyjna a życie codzienne, Warszawa 2004.

Wszołek S., Wprowadzenie do filozofii religii, Kraków 2004.

Zimbardo P., Efekt Lucyfera. Dlaczego dobrzy ludzie czyniq zło?, Warszawa 2008.

Projekt został sfinansowany ze środków Narodowego Centrum Nauki przyznanych na podstawie decyzji numer DEC-2013/09/N/HS1/02868. 